\title{
PETA PENGGUNAAN E-LEARNING OLEH DOSEN FAKULTAS EKONOMI DAN BISNIS PASCA HIBAH SPADA
}

\author{
Meika Kurnia Puji Rahayu \\ Program Studi Manajemen, Fakultas Ekonomi dan Bisnis, Universitas Muhammadiyah \\ Yogyakarta \\ Yogyakarta, Indonesia \\ meika_kurnia@umy.ac.id
}

\begin{abstract}
Abstrak
Penelitian ini bertujuan untuk menganalisis penggunaan e-learning di kalangan dosen Fakultas Ekonomi dan Bisnis Universitas Muhammadiyah Yogyakarta pasca diberlakukannya kebijakan kuliah daring dan hibah SPADA. Dasar dilakukannya penelitian ini adalah kenyataan bahwa penggunaan elearning oleh dosen UMY belum sebanding dengan investasi yang sudah dilakukan. Masih banyak dosen belum optimal dalam menggunakan e-learning untuk meningkatkan kualitas mengajar. Subjek penelitian adalah dosen Fakultas Ekonomi dan Bisnis dengan sampel sejumlah 65 orang. Data dikumpulkan menggunakan metode teknik dokumentasi dan physical artefacts. Analisis data dilakukan dengan metode deskriptif. Hasil penelitian menunjukkan ada perubahan signifikan dalam hal jumlah dosen yang memiliki akun e-learning setelah implementasi kebijakan terkait dengan penggunaan e-learning di proses belajar mengajar. Namun hal ini belum diikuti dengan penggunaan e-learning yang optimal. Sebagian besar dosen menggunakan e-learning hanya untuk mengunggah materi perkuliahan dalam bentuk PowerPoint. Sedikit dari responden menggunakan e-learning untuk diskusi atau ujian online.
\end{abstract}

Kata kunci : penggunaan e-learning, hibah SPADA, dosen

\begin{abstract}
This study aims to analyse the use of e-learning among lecturers of the Faculty of Economics and Business, Universitas Muhammadiyah Yogyakarta after the implementation of an online lecture policy and SPADA grants. This research is based on the fact that the use of e-learning by UMY lecturers is not comparable with the investment that has been made. There are still many lecturers who have not been optimal in using e-learning to improve the quality of teaching. The research subjects were lecturers of the Faculty of Economics and Business with a sample of 65 people. Data was collected using documentation techniques and physical artefacts. Data analysis was carried out by qualitative-descriptive method. The results show that there were significant changes in the number of lecturers who have e-learning accounts after the implementation of university policy in term of use of e-learning in teaching and learning. However, this has not been followed by an optimal use of e-learning since most lecturers use e-learning only to upload lecture material in PowerPoint. $A$ few of the respondents used e-learning for online discussions or exams.
\end{abstract}

Keywords: ise of e-learning, SPADA grant, lecturers

\section{PENDAHULUAN}

Memasuki era revolusi industri 4.0, Teknologi Informasi dan Komunikasi (TIK) semakin menjadi kebutuhan dasar dalam kehidupan manusia di segala aspek/bidang. Era 
Jurnal Manajemen Bisnis, Vol 9. No 2, September 2018, E-ISSN:2622-6308 P-ISSN:2086-8200

Website: http://journal.umy.ac.id/index.php/mb

DOI:10.18196/mb.9264

ini diidentifikasi sebagai disrupsi berbagai aktivitas manusia, termasuk Pendidikan Tinggi (Behara, 2015; Weisblat, 2017). Perkembangan Internet dan teknologi digital mendorong terciptanya dunia tanpa batas, lingkungan tanpa batas, pasar tanpa batas, dan juga pendidikan tanpa batas.

TIK saat ini hadir sebagai pendorong perubahan yang signifikan dalam institusi pendidikan, khususnya Perguruan Tinggi (PT). Selain memunculkan pendidikan tanpa batas (borderless education), secara khusus, unsur-unsur TIK, seperti perangkat keras, perangkat lunak, dan Internet, memungkinkan PT untuk memperbaiki proses manajerialnya serta mempermudah kegiatan rutin yang dilakukan. Proses bisnis PT menjadi lebih simpel dan lebih cepat, misalnya penggunaan metode online dan elektronik untuk proses admisi, registrasi, dan key-in mata kuliah. TIK, seperti teknologi email, video, dan telekonferensi bahkan mampu meningkatkan komunikasi antar civitas akademik, misalnya antara dosen dan mahasiswa, antara dosen dan dosen, atau mahasiswa dengan staf (Chase, 2013; Gan, 2014).

Studi empiris yang telah dilakukan kurang lebih dua warsa belakangan ini membuktikan bahwa penggunaan teknologi online dalam perkuliahan mampu memperbaiki kualitas pengajaran dan pembelajaran di PT (Alavi et al., 1995; Alavi et al., 1997; Ali et al., 2013; Fu, 2013; Leidner \& Jarvenpaa, 1995; Nawaz et al., 2011; Noguera \& Watson, 2004; Noor-Ul-Amin, 2013; Reigeluth et al., 2008; Renes \& Strange, 2011; Sarkar, 2012). Penggunaan tersebut membantu Fakultas dan Program Studi untuk mendesain program perkuliahan yang memampukan dosen dan mahasiswa memiliki lebih banyak kesempatan untuk berbagi dan membangun pengetahuan (Kabir, 2012; Rienties \& Townsend, 2012). Studi juga mengungkapkan bahwa penggunaan teknologi online dalam pengajaran dan pembelajaran memungkinkan mahasiswa mendapatkan pengalaman pembelajaran yang lebih baik di kelas (Fu, 2013; Noor-Ul-Amin, 2013).

Lebih khusus lagi, integrasi TIK ke dalam pengajaran dan pembelajaran juga secara signifikan mengubah cara dosen merancang dan menyampaikan perkuliahan (Rienties \& Townsend, 2012; Snyder, 2003; Wright et al., 2013). TIK memungkinkan para dosen menerapkan metodologi pembelajaran yang lebih aktif dengan menggunakan platform pengajaran dan pembelajaran online, misalnya Learning Management Systems (Gabrielsson et al., 2010). Platform online memungkinkan dosen merancang dan memberikan pembelajaran 
Jurnal Manajemen Bisnis, Vol 9. No 2, September 2018, E-ISSN:2622-6308 P-ISSN:2086-8200

Website: http://journal.umy.ac.id/index.php/mb

DOI:10.18196/mb.9264

kolaboratif (Kabir 2012; Lane, 2008). Platform semacam ini juga memungkinkan dosen dan mahasiswa untuk mengakses informasi melalui berbagai sumber online, seperti $e$-book, $e$ journal, dan sumber online lainnya. Konsekuensinya, dosen tidak lagi menjadi pusat penyebaran informasi karena mahasiswa sangat mungkin untuk mengumpulkan, menganalisa, dan bahkan menghasilkan informasi sendiri (Bates \& Sangrà, 2011; Thomas, 2011).

Sedemikian banyak nilai strategis TIK dalam meningkatkan kualitas pembelajaran di PT dan juga sebagai pendorong perubahan dalam institusi PT, sehingga integrasi TIK dalam proses pengajaran dan pembelajaran menjadi salah satu hal yang perlu mendapat perhatian khusus. Merespon perubahan lingkungan Pendidikan yang sedemikian rupa, maka Kementrian Pendidikan Nasional (Kemendiknas) melalui Direktorat Jendral Pendidikan Tinggi (Dirjen Dikti) telah mendesain suatu strategi Pendidikan nasional, khususnya di lingkup Perguruan Tinggi yang memasukkan unsur inegrasi TIK ke dalam proses belajar mengajar. Dalam Higher Education Long Term Strategy (HELTS) 2003-2010, dirumuskan bahwa salah satu ciri khas mencapai keunggulan proses belajar mengajar di PT adalah penggunaan teknologi informasi. Setelah Dirjen Dikti bergabung ke dalam Kementrian Riset dan Teknologi, perhatian pada isu penting penggunaan TIK masih dilanjutkan. Dalam visi Kementrian Riset, Teknologi, dan Pendidikan Tinggi (Kemenristekdikti) 2015-2019 jelas terlihat perhatian khusus pemerintah pada peningkatan kualitas pendidikan dengan dukungan teknologi, yaitu "Terwujudnya pendidikan tinggi yang bermutu serta kemampuan iptek dan inovasi untuk mendukung daya saing bangsa" (Permenristekdikti 2015). Visi tersebut dijabarkan dalam 5 (Suliman, 2010) sasaran strategis sesuai dengan permasalahan-permasalahan yang harus diselesaikan dalam kurun waktu 2015-2019. Sasaran strategis tersebut adalah : 1. Meningkatnya kualitas pembelajaran dan kemahasiswaan pendidikan tinggi; 2. Meningkatnya kualitas kelembagaan Iptek dan pendidikan tinggi; 3. Meningkatnya relevansi, kualitas, dan kuantitas sumber daya Iptek dan pendidikan tinggi; 4. Meningkatnya relevansi dan produktivitas riset dan pengembangan; dan 5. Menguatnya kapasitas inovasi.

Merespon kebijakan Dikti, Universitas Muhammadiyah Yogyakarta (UMY), sebagai salah satu perguruan tinggi swasta terkemuka di Indonesia, telah mengintegrasikan TIK ke dalam proses perkuliahan sejak tahun 2007 dengan mengembangkan e-learning. E-learning 
Jurnal Manajemen Bisnis, Vol 9. No 2, September 2018, E-ISSN:2622-6308 P-ISSN:2086-8200

Website: http://journal.umy.ac.id/index.php/mb

DOI:10.18196/mb.9264

merupakan teknologi pembelajaran yang memungkinkan staf pengajar memberikan layanan kepada mahasiswa kapan saja dan di masa saja. Sebaliknya, mahasiswa akan memperoleh pengalaman belajar yang lebih fleksibel mengingat dengan teknologi e-learning materi perkuliahan dapat diakses kapan saja, di masa saja. Menurut Panen (2016) e-learning memiliki nilai inovatif karena memberikan nuansa baru dalam proses belajar mengajar yang berbeda dengan pembelajaran tatap muka biasa. Platform ini bisa digunakan untuk melaksanakan kegiatan perkuliahan jarak jauh (daring) atau juga digunakan untuk melengkapi metode pembelajaran tatap muka (blended learning).

Pengintegrasian e-learning ke dalam proses bisnis akademik di UMY merupakan strategi UMY untuk meningkatkan relevansi perkuliahan dengan tuntutan angkatan kerja abad ke-21. Dalam visi UMY, secara tegas disebutkan bahwa penguasaan teknologi adalah menjadi salah satu cita-cita UMY pada civitas akademikanya. Secara khusus, e-learning di UMY dirancang untuk memenuhi empat tujuan. Pertama, meningkatkan kualitas komunikasi antara dosen dan mahasiswa. Yang kedua adalah meningkatkan kompetensi mahasiswa menjadi pribadi yang analitis dan kritis. Ketiga, merangsang fakultas dan mahasiswa dalam mengupdate informasi terbaru dari berbagai sumber referensi. Tujuan terakhir adalah untuk mendukung pembelajaran mandiri siswa. Platform online ini dilengkapi dengan berbagai fitur, seperti kursus online, forum diskusi, chat room, papan pengumuman, tes online, dan sistem penilaian online. Dosen dapat mengunggah materi kuliah mereka atau memposting kuis online melalui eLearning UMY.

Sayangnya, meskipun pengintegrasian TIK ke dalam proses belajar mengajar di PT adalah bermanfaat dan penting, namun penggunaannya masih belum sesuai harapan. Fry dan Love (2011) menemukan bahwa masih banyak dosen yang tidak menggunakan TIK untuk tujuan pembelajaran. Alih-alih, dosen menggunakan TIK hanya untuk penyimpanan data dan materi pelajaran. Dosen menggunakan TIK terutama untuk tugas pengolah kata atau spreadsheet. Praktik pengajaran dosen bahkan masih teacher centered, menunjukkan bahwa mereka tidak menyadari keuntungan menggunakan TIK untuk memperbaiki pengajaran dan pembelajaran. Bahkan dalam penelitian lain ditemukan bahwa kemampuan menggunakan TIK di kalangan dosen PT masih lamban (Blin \& Munro 2008; Kirkup \& Kirkwood 2005; Redmann \& Kotrlik 2004; Watty et al., 2015). Hal yang hampir sama juga ditemukan di UMY (Anggrareni, 2017). Meskipun UMY telah melakukan investasi mahal terkait penggunaan e-learning, namun penggunaannya masih rendah (Anggrareni, 2017). 
Jurnal Manajemen Bisnis, Vol 9. No 2, September 2018, E-ISSN:2622-6308 P-ISSN:2086-8200

Website: http://journal.umy.ac.id/index.php/mb

DOI:10.18196/mb.9264

Jumlah dosen yang mengintegrasikan e-learning ke dalam proses perkuliahan rata-rata 30\% (Anggrareni, 2017).

Mengatasi permasalahan tersebut, pimpinan Universitas melalui Wakil Rektor bidang Akademik dan Penelitian mengeluarkan kebijakan implementasi kuliah daring dalam bentuk blended learning. Kebijakan ini disertai dengan pemberian penghargaan bagi dosen yang menggunakan e-learning secara aktif dalam perkuliahannya. Program ini dinamakan hibah SPADA. Selain itu, pimpinan Universitas juga menugaskan program studi-program studi di UMY untuk mendesain pelatihan-pelatihan e-learning bagi dosen atau kegiatan-kegiatan yang mendorong dosen untuk aktif mengintegrasikan e-learning ke dalam perkuliahannya.

Penelitian ini bertujuan menganalisis perubahan yang terjadi dalam hal penggunaan e-learning pasca kebijakan kuliah daring dan hibah SPADA di UMY. Objek penelitian adalah Fakultas Ekonomi dan Bisnis. Hasil penelitian memberikan gambaran efektifitas kebijakan yang diberlakukan dan menjadi pertimbangan perbaikan proses pembelajaran blended learning di UMY secara umum.

\section{KAJIAN TEORI}

\section{E-Learning}

E-Learning atau electronic learning adalah proses pembelajaran dengan menggunakan TIK, khususnya menggunakan media yang berbasis Internet. Istilah e-learning sering dimaknai sama dengan beberapa istilah dalam teknologi pendidikan, seperti on-line learning, virtual classroom dan virtual learning. Menurut Churchill (2007), konsep e-learning meliputi lima hal, yaitu (1) perpaduan antara Internet dengan konsep pembelajaran, atau pembelajaran yang menggunakan internet, (2) penggunaan teknologi jaringan (Web) untuk menciptakan, menumbuhkan, menyebarluaskan, dan memudahkan proses pembelajaran tanpa terikat oleh waktu dan tempat, (3) upaya membentuk (sikap) seseorang agar tidak individualistik, berwawasan luas, dinamis dalam belajar, mampu mengembangkan pengetahuan, serta menjadi pembelajar dan praktisi yang mampu mengembangkan keahlian, (4) upaya mengembangkan akuntabilitas, meningkatkan kecerdasan, dan memberikan kesempatan bagi individu dan organisasi untuk tetap mengikuti perkembangan jaman melalui dunia Internet, dan (5) suatu kekuatan yang membuat 
Jurnal Manajemen Bisnis, Vol 9. No 2, September 2018, E-ISSN:2622-6308 P-ISSN:2086-8200

Website: http://journal.umy.ac.id/index.php/mb

DOI:10.18196/mb.9264

individu maupun organisasi untuk berkompetisi dan memberikan kesempatan kepada mereka untuk tetap mengikuti perubahan ekonomi secara global.

\section{Teori Penggunaan Teknologi}

Literatur menunjukkan banyak model teoretis yang mapan yang digunakan untuk mengkaji penggunaan TIK. Kim dan Malhotra (2005) mengidentifikasi empat model yang telah sering digunakan untuk mempelajari penggunaan TIK. Termasuk di dalamnya adalah Theory of Reasoned Action (TRA) (Fishbein \& Ajzen, 1975), Theory of Planned Behavior (TPB) (Ajzen, 1985), Model Penerimaan Teknologi atau Technology Acceptance Model (TAM) (Davis, 1985, 1989), dan Innovation Diffusion Theory (IDT) (Rogers, 1983).

Di antara keempat model tersebut, banyak ilmuwan mengakui TAM sebagai teori yang paling terkenal dan model yang valid untuk menjelaskan penggunaan TIK (Chuttur, 2009; King \& He, 2006; Marangunić \& Granić, 2015; Šumak et al., 2011; Venkatesh \& Bala, 2008; Wu et al., 2011.; Yousafzai et al., 2007). Selain banyak diterapkan dalam penelitian di dalam organisasi bisnis (Blanca et al., 2008; Davis, 1989; Dulcic et al., 2012; Ha \& Stoel, 2009; Hernández et al., 2008.; Pasaoglu, 2011; Thomas, 2012; Venkatesh \& Bala, 2008; Venkatesh \& Davis, 2000), TAM juga diterapkan di lingkungan pendidikan tinggi (Adewole-Odeshi, 2014; Al-Adwan et al., 2013; Edmunds et al., 2012; Fathema et al., 2015; Iqbal \& Bhatti, 2015; Jan \& Contreras, 2011; Lane \& Stagg, 2014 ; Raman, 2011; Shahrabi et al., 2013).

Meskipun TAM telah dikenal sebagai model penggunaan TIK yang handal, model ini mendapat kritikan. Model ini dikatakan sebagai model yang pelit karena hanya memiliki dua variable prektor utama, yaitu perceived ease of use (PEU), dan perceived usefulness (PU). Selanjutnya, Turner et al. (2010) meragukan model ini apakah memprediksi penggunaan aktual mengingat lebih banyak penelitian fokus pada niat menggunakan (intention to use) teknologi. TAM mengukur penggunaan teknologi dari tingkat keseringan (frekuensi) menggunakan. Pernyataan yang diajukan untuk menginvestigasi penggunaan teknologi sederhana, misalnya “Dalam sehari, berapa jam rata-rata Anda menggunakan teknologi?". Anggraeni (2007) menyarankan untuk mengeksplor lebih dalam terkait penggunaan teknologi ini, tidak hanya menyangkut seberapa sering menggunakan namun bagaimana seseorang menggunakan teknologi. 
Jurnal Manajemen Bisnis, Vol 9. No 2, September 2018, E-ISSN:2622-6308 P-ISSN:2086-8200

Website: http://journal.umy.ac.id/index.php/mb

DOI:10.18196/mb.9264

\section{Penelitian terkait Penggunaan TIK di Perguruan Tinggi}

Literatur tentang TIK dan pendidikan menunjukkan bahwa para ahli pendidikan menganggap TIK sebagai sarana penting untuk meningkatkan pengajaran dan pembelajaran yang lebih baik (Khan et al 2012). TIK adalah katalisator perubahan dalam metode pengajaran di institusi PT, dari metode pengajaran kelas tradisional hingga evolusi berbagai perkuliahan online (Ali et al 2013; Nawaz et al., 2011; Sarkar 2012). Selain itu, integrasi TIK ke dalam desain pengajaran dan pembelajaran memungkinkan dosen mengubah pendekatan pengajaran mereka dari pengajaran berpusat pada guru ke desain pembelajaran yang berpusat pada siswa dan lebih kolaboratif (Kabir 2012; Lane 2008; Rienties \& Townsend 2012). Dalam konsep pembelajaran baru ini, dosen mampu berinovasi, mempercepat, memperkaya, dan memperdalam keterampilan, memotivasi dan melibatkan siswa, dan memberikan pengalaman belajar yang mewakili praktik kerja (Fu 2013; Noor-UlAmin 2013). Sebagai tambahan, TIK mereformasi penyebaran informasi di institusi PT. Pencarian dan berbagi pengetahuan menjadi lebih sederhana melalui sumber online, termasuk versi jurnal lengkap, e-book dan sumber utama (Hudson 2010). TIK juga memperluas akses ke pendidikan tinggi (Bates \& Sangrà 2011; Fu 2013). Platform pengajaran online memungkinkan setiap orang yang memenuhi persyaratan universitas untuk mendaftar dan belajar tanpa terikat oleh waktu dan tempat. Belajar dapat terjadi kapan saja dan dimana saja karena platform pengajaran online dapat diakses kapan saja.

Sejauh ini bagian terbesar dari literatur tentang implementasi TIK di PT fokus pada faktor-faktor yang mempengaruhi keberhasilan integrasi (Carr 2011; Persaud 2006; Thomas 2011). Faktor tersebut dapat dibagi menjadi dua kelompok. Mereka adalah faktor terkait dengan individu dan faktor terkait dengan organisasi. Beberapa faktor terkait individu yang dapat mendukung atau sebaliknya menghambat penggunaan teknologi adalah karakteristik individu, gender dan pengalaman mengajar (Thomas 2011), staf terampil atau tidak terampil (Kim 2011; White 2004), dan keyakinan pengajar (dosen) tentang teknologi (Ertmer 1999). Sementara faktor terkait organisasi, diantaranya adalah struktur administrasi, infrastruktur, kualitas program dan kompensasi, serta jaringan telekomunikasi, ketersediaan fasilitas internet. Secara umum Ertmer (1999) menyebutkan dukungan dari organisasi sebagai faktor yang mempengaruhi penggunaan teknologi di kalangan pengajar. 
Jurnal Manajemen Bisnis, Vol 9. No 2, September 2018, E-ISSN:2622-6308 P-ISSN:2086-8200

Website: http://journal.umy.ac.id/index.php/mb

DOI:10.18196/mb.9264

Dalam penelitian ini, dikaji bagaimana peta penggunaan teknologi untuk kegiatan perkuliahan setelah adanya dukungan organisasi yang berupa kebijakan dan insentif. Dalam hal ini adalah bagaimana pengaruh diberlakukannya kebijakan kuliah daring dan insentif penggunaan e-learning terhadap bagaimana dosen menggunakan e-learning dalam mengajarnya.

\section{METODE PENELITIAN}

Pendekatan yang digunakan dalam penelitian ini adalah pendekatan deskriptif. Pendekatan ini memungkinkan peneliti menganalisis gambaran faktual dan akurat mengenai fakta-fakta terkait dengan penggunaan TIK, khususnya e-learning di PT. Menurut Sugiyono (2015 : 53), "Penelitian deskriptif adalah penelitian yang dilakukan untuk mengetahui keberadaan variabel mandiri, baik hanya pada satu variabel atau lebih tanpa membuat perbandingan atau menghubungkan dengan variabel lainnya (variabel mandiri adalah variabel yang berdiri sendiri, bukan variabel independen, karena kalau variabel independen selalu dipasangkan dengan variabel dependen".

Obyek penelitian meliputi variabel yang menjadi pusat pemikiran diadakannya suatu penelitian. Obyek penelitian adalah suatu atribut atau sifat atau nilai dari orang, objek atau kegiatan yang mempunyai variasi tertentu yang ditetapkan oleh peneliti untuk dipelajari dan kemudian ditarik kesimpulannya (Sugiyono 2015). Sementara, subyek penelitian adalah orang yang diminta memberikan keterangan tentang suatu fakta atau pendapat. Obyek penelitian ini adalah penggunaan e-learning di UMY. Subyek dalam penelitian ini dosen FEB UMY. Yang dimaksud dengan dosen FEB UMY adalah dosen tetap, baik DPK maupun Yayasan.

Populasi dalam penelitian ini adalah dosen tetap FEB UMY berjumlah 77 orang. Penelitian ini tidak melibatkan seluruh populasi, melainkan menggunakan sampel yaitu bagian dari jumlah dan karakteristik yang dimiliki oleh populasi tersebut. Mengingat jumlah populasi dapat dtentukan, dan setiap anggota populasi memiliki peluang yang sama untuk dipilih menjadi angota sampel, maka teknik Pengambilan sampelnya dapat dikategorikan ke dalam teknik Probability Sampling (Sekaran 2016; Sugiyono 2015).

Jumlah sampel ditentukan menggunakan rumus Slovin dengan tingkat kesalahan toleransi sebesar $5 \%$. 
Jurnal Manajemen Bisnis, Vol 9. No 2, September 2018, E-ISSN:2622-6308 P-ISSN:2086-8200

Website: http://journal.umy.ac.id/index.php/mb

DOI:10.18196/mb.9264

$$
n=\frac{\mathrm{N}}{1+\mathrm{N}(\mathrm{e})^{2}}
$$

\section{Keterangan:}

$$
\mathrm{N}=\text { Ukuran Populasi }
$$

$\mathrm{n} \quad=$ Ukuran Sampel

$\mathrm{e}=$ Margin of Error, yaitu persen kelonggaran ketidak telitian karena kesalahan mengambil sampel yang masih dapat ditolerir sebesar 5\%

$$
\begin{aligned}
& n=\frac{\mathrm{N}}{1+\mathrm{N}(\mathrm{e})} \\
& n=\frac{77}{1+77(0,05)^{2}} \\
& n=64,57 \text { atau mendekati } 65 .
\end{aligned}
$$

Teknik Pengambilan sampel menggunakan Simple Random Sampling atau sampel acak sederhana. Teknik ini dilakukan dengan cara mengambil sampel tanpa memperhatikan strata dalam populasi.

Data utama yang dikumpulkan adalah data sekunder, yaitu data yang tidak langsung didapatkan dari sumber data (Sugiyono 2015). Dalam penelitian ini data dikumpulkan menggunakan teknik dokumentasi dan physical artefacts (Alam 2005; Yin 2009). Dokumen-dokumen termasuk menggunakan informasi publik yang tersedia, seperti informasi dari laporan penelitian dan situs web Universitas. Physical artefacts termasuk mengamati platform pengajaran dan pembelajaran online yang digunakan oleh dosen FEB UMY yaitu e-learning FEB UMY. Namun demikian, untuk mendukung data sekunder juga dikumpulkan data primer melalui wawancara. Dengan menggunakan teknik ini, peneliti mengumpulkan data berupa:

1. Apakah responden memiliki akun e-learning?

2. Apakah responden aktif menggunakannya (mengupload materi, menggunakan $e$ larning untuk diskusi, penugasan dan kuis, serta melakukan penilaian).

3. Kebijakan yang sudah dilakukan di tingkat program studi maupun universitas. 
Jurnal Manajemen Bisnis, Vol 9. No 2, September 2018, E-ISSN:2622-6308 P-ISSN:2086-8200

Website: http://journal.umy.ac.id/index.php/mb

DOI:10.18196/mb.9264

Teknik analisis data yang dilakukan adalah analisis data deskriptif kualitatif. Menurut Sugiyono (2015), teknik ini merupakan suatu cara dalam meneliti status sekelompok manusia, suatu objek, kondisi, sistem pemikiran atau juga peristiwa masa sekarang. Dalam hal ini peneliti melakukan pengumpulan data secara mendalam, melakukan pengamatan, mendeskripsikan data yang sudah terkumpul sampai melaporkan. Tujuan dari analisis ini tidak untuk membuat kesimpulan yang berlaku dalam umum atau generalisasi.

\section{HASIL PENELITIAN DAN PEMBAHASAN}

Seperti yang dilaporkan dalam sub bab sebelumnya target sampel dalam penelitian ini sebanyak 65 dosen FEB UMY yang mencakup dosen dari ketiga program studi yaitu Manajemen, Akuntansi dan Ekonomi Pembangunan. Dalam tabel 1 terlihat distribusi sampel di tiap program studi.

Tabel 1. Distribusi Sampel/Responden di Tiap Program Studi

\begin{tabular}{l|c|c|c}
\hline \multicolumn{1}{c|}{ Progam Studi } & Jumlah Dosen & $\begin{array}{c}\text { Proporsi jumlah } \\
\text { dosen per prodi }\end{array}$ & $\begin{array}{c}\text { Jumlah Sampel } \\
\text { /Responden }\end{array}$ \\
\hline Manajemen & 29 & $38 \%$ & 24 \\
\hline Akuntansi & 30 & $39 \%$ & 25 \\
\hline Ek. Pembangunan & 18 & $23 \%$ & 15 \\
\hline Total & $\mathbf{7 7}$ & $\mathbf{1 0 0} \%$ & $\mathbf{6 5}$ \\
\hline
\end{tabular}

Analisis data tahap awal adalah menganalisis hasil pengamatan, pengecekan, dan perhitungan penggunaan e-learning dosen FEB UMY melalui http://elearning.feb.umy.ac.id/. Untuk kepentingan penelitian, peneliti memperoleh hak akses ke akun e-learning tiga progam studi sehingga dapat mengamati penggunaan $e$ learning masing-masing dosen. Akses ke akun tiap dosen dilakukan pada semester genap 2017/2018 dan gasal 2018/2019.

Terlihat sangat jelas perubahan jumlah kepemilikan akun e-elarning sebelum dan sesudah kebijakan SPADA diberlakukan. Diagram 1 menunjukkan semua dosen FEB UMY (100\%) memiliki akun di http://elearning.feb.umy.ac.id/. Data ini tentunya sangat menggembirakan karena 3 (tiga) tahun sebelumnya, jumlah dosen yang memiliki akun di http:// elearning.feb.umy.ac.id/ hanya 30\% (Anggraeni, 2017). 


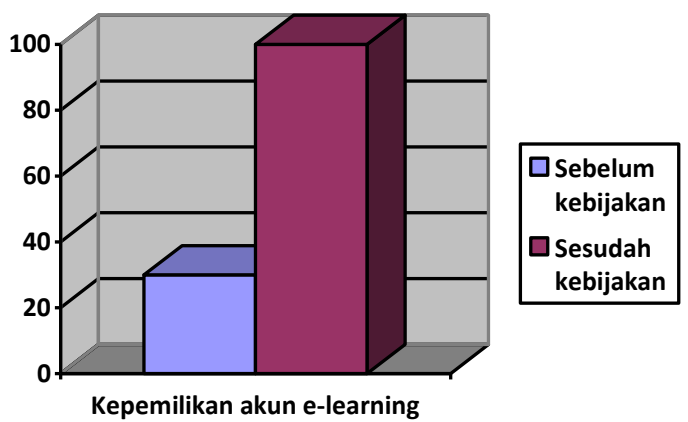

\section{Gambar 1. Diagram Perubahan Kepemilikan akun e-learning}

Jika dalam penelitian Anggraeni (2017) dinyatakan bahwa dosen FEB UMY menggunakan e-learning hanya untuk mengupload materi perkuliahan saja, pada penelitian ini, setelah diimplemenatsikan kebijakan SPADA, terlihat perubahan yang sangat signifikan. Jumlah dosen yang mengupload materi kuliah di http://elearning.feb.umy.ac.id/ juga meningkat, meski persentase di tiap program studi bervariasi. Diagram 2 memperlihatkan, program studi Manajemen memiliki persentase jumlah dosen terbanyak yang mengupload materi ke akun e-learning, yaitu sebanyak 96\%. Sementara program studi Akuntansi hanya 64\% dan Ekonomi Pembangunan 47\%. Jenis materi yang diupload juga bervariasi. Sebagian besar dosen mengupload materi dalam bentuk PowerPoint (PPT). Selain PPT dosen juga mengunggah link-link ke web site tertentu serta artikel-artikel dari jurnal ilmiah.

Dukungan organisasi di level universitas dan program studi berpenagruh pada pencapaian tersebut di atas. Hasil wawancara menunjukkan bahwa selain mengelaurkan kebijakan SPADA, pimpinan Universitas juga memberi kewenangan kepada program studi di lingkup UMY untuk melakukan kegiatan peningkatan kualitas belajar mengajar, termasuk termasuk penggunaan e-learning. Hasil analisis data berdasar studi dokumen, yaitu menggunakan dokumen Laporan kerja unit kerja (LKUK) FEB UMY tahun 2017/2018, menunjukkan bahwa setelah kebijakan tersebut di atas diumumkan, masing-masing program studi di FEB UMY telah mendesain dan melakukan program pelatihan e-learning pada semester genap 2017/2018. Pelatihan yang diberikan meliputi pelatihan dasar yaitu bagaimana membuka akun e-learning dan mengupload materi melalui e-learning. 
Jurnal Manajemen Bisnis, Vol 9. No 2, September 2018, E-ISSN:2622-6308 P-ISSN:2086-8200

Website: http://journal.umy.ac.id/index.php/mb

DOI:10.18196/mb.9264

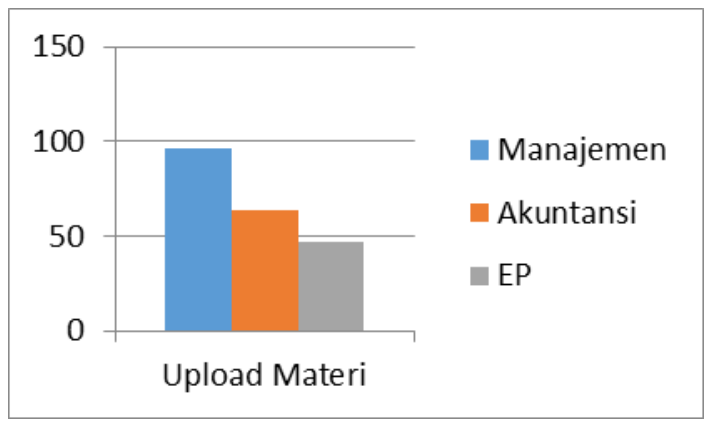

\section{Gambar 2. Diagram Persentase jumlah dosen yang mengupload materi di} http://elearning.feb.umy.ac.id

Dukungan organisasi lain yang mendorong peningkatan jumlah dosen yang mengunggah materi kuliah di akun e-learning masing-masing adalah adanya insentif bagi mereka. Menurut keterangan pimpinan program studi, insentif tersebut sengaja didesain untuk untuk mendorong dosen mengaktifkan akun e-learningnya.

Namun demikian, belum semua dosen aktif menggunakan akunnya untuk mendukung proses perkuliahan. Dosen Akuntansi cukup aktif memberikan tugas kepada mahasiswa melalui akun e-learning (56\%). Akan tetapi, seperti terlihat dalam diagram 3, belum ada separuh dosen Manajemen dan Ekonomi Pembangunan menggunakan akun elearningnya untuk memberikan penugasan kepada mahasiswa (masing-masing $46 \%$ dan $40 \%)$.

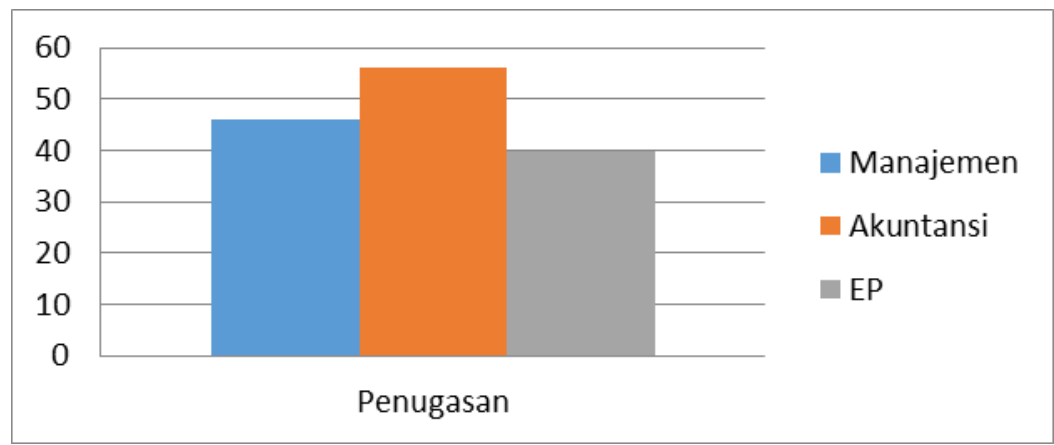

Gambar 3. Diagram Persentase jumlah dosen yang memberikan tugas melalui http://elearning.feb.umy.ac.id

Sementara itu, persentase dosen yang menggunakan e-learning untuk melakukan diskusi dan kuis online menunjukkan data yang sama. Secara berurutan, seperti 
Jurnal Manajemen Bisnis, Vol 9. No 2, September 2018, E-ISSN:2622-6308 P-ISSN:2086-8200

Website: http://journal.umy.ac.id/index.php/mb

DOI:10.18196/mb.9264

diperlihatkan dalam Diagram 5.3, Manajemen 42\%, Akuntansi 40\% Ekonomi Pembangunan $40 \%$.

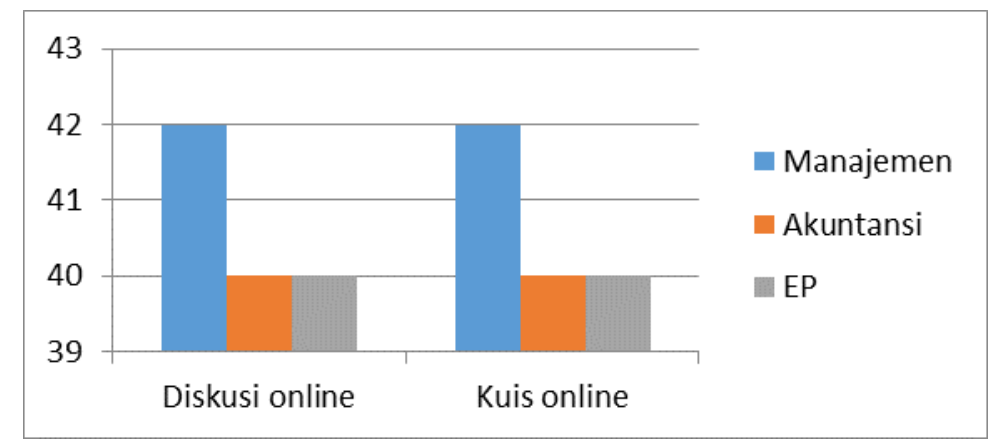

Gambar 4. Diagram Persentase jumlah dosen yang memberikan diskusi dan kuis online http://elearning.feb.umy.ac.id

\section{SIMPULAN DAN SARAN}

Hasil analisis data menunjukkan peta penggunaan e-learning di kalangan dosen FEB UMY pasca diimplementasikannya kebijakan kuliah daring dan hibah SPADA di UMY. Semua dosen UMY telah memiliki akun e-learning. Hal ini mengindikasikan ada pengaruh positif dari kebijakan kuliah daring dan hibah SPADA.

Namun, meskipun sudah memiliki akun, belum semua dosen aktif menggunakan akun e-learningnya untuk mendukung proses perkuliahan. Program studi Manajemen memiliki jumlah dosen terbanyak yang mengupload materi di akun e-learning. Namun persentase dosen Manajemen yang menggunakan e-learning untuk diskusi dan kuis online masih di bawah 50\%. Hal yang serupa juga terjadi di kedua program studi lainnya yaitu Akuntansi dan Ekonomi Pembangunan. Semua dosen telah memiliki akun e-learning, namun belum semua aktif menggunakannya untuk mendukung kegiatan perkuliahan seperti penugasan, diskusi online dan ujian.

Dari pembahasan di atas dapat disimpulkan bahwa dukungan organisasi berupa kebijakan pimpinan terkait penggunaan TIK dalam pembelajaran (salah satunya e-learning) dan sistem reward yang relevan (hibah SPADA dan insentif) menjadi faktor-faktor pendukung penggunaan TIK dalam proses belajar mengajar. Hasil penelitian ini mendukung penelitian-penelitian sebelumnya, misalnya Balanskat et al. (2006) dan Ertmer (1999). 
Jurnal Manajemen Bisnis, Vol 9. No 2, September 2018, E-ISSN:2622-6308 P-ISSN:2086-8200

Website: http://journal.umy.ac.id/index.php/mb

DOI:10.18196/mb.9264

Namun demikian, mengingat penggunaan e-learning masih belum optimal, maka mengacu pada hasil penelitian ini, dapat disampaikan beberapa saran sebagai berikut:

1. Pimpinan Universitas perlu melakukan evaluasi penggunaan e-learning di kalangan dosen untuk memastikan tujuan pemberian hibah berjalan dengan efektif.

2. Pengelola program studi perlu mengidentifikasi faktor-faktor yang menyebabkan belum semua dosen menggunakan e-learning dengan optimal.

3. Pengelola program studi perlu mendesain program yang dapat memotivasi dosen untuk aktif menggunakan e-learning.

\section{DAFTAR PUSTAKA}

Adewole-Odeshi, E. (2014). Attitude of Students Towards E-learning in South-West Nigerian Universities: An Application of Technology Acceptance Model. Library Philosophy and Practice, 2014(1), 0_1.

Al-Adwan, A., Al-Adwan, A., \& Smedley, J. (2013). Exploring Students Acceptance of ELearning Using Technology Acceptance Model in Jordanian Universities. International Journal of Education and Development using Information and Communication Technology, 9(2), 4 .

Ajzen, I. (1985). From Intentions to Actions: A Theory of Planned Behavior. In K. J. \& B. J. (Eds.), Action control: From cognition to behavior (pp. 11-39). Berlin, Heidelber: New York: Springer-Verlag.

Alavi, M., Wheeler, B. C., \& Valacich, J. S. (1995). Using IT to Reengineer Business Education: An Exploratory Investigation of Collaborative Telelearning. MIS Quarterly, 293-312.

Alavi, M., Yoo, Y., \& Vogel, D. R. (1997). Using Information Technology to Add Value to Management Education. Academy of management Journal, 40(6), 1310-1333.

Ali, G., Haolader, F. A., \& Muhammad, K. (2013). The Role of ICT to Make TeachingLearning Effective in Higher Institutions of Learning in Uganda. International Journal of Innovative Research in Science, Engineering and Technology, 2(8), 4061-4073.

Anggraeni, M. K. P. R. D. (2017). Information and Communication Technology (ICT) Use in Teaching and Learning in Higher Education Business Schools. A Comparative Study. (Doctoral), Charles Darwin University, Darwin.

Bates, T., \& Sangrà, A. (2011). Managing Technology in Higher Education: Strategies for Transforming Teaching and Learning. San Francisco: Jossey-Bass.

Behara, R. S., \& Davis, M. M. (2015). Navigating Disruptive Innovation in Undergraduate Business Education. Decision Sciences Journal of Innovative Education, 13(3), 305-326.

Blanca, H., Julio, J., \& Jose, M. M. (2008). Business Acceptance of Information Technology: Expanding TAM Using Industry Sector and Technological Compatibility. International Journal of Enterprise Information Systems (IJEIS), 4(4), 62-79. doi:10.4018/jeis.2008100105

Blin, F., \& Munro, M. (2008). Why Hasn't Technology Disrupted Academics' Teaching Practices? Understanding Resistance To Change Through The Lens Of Activity Theory. Computers E Education, 50(2), 475-490. 
Jurnal Manajemen Bisnis, Vol 9. No 2, September 2018, E-ISSN:2622-6308 P-ISSN:2086-8200

Website: http://journal.umy.ac.id/index.php/mb

DOI:10.18196/mb.9264

Carr, T. (2010). An Examination of Leadership Styles in Implementing Instructional Technology: A Case Study to Examine the Elementary School Principal Perspective. (Doctor of Education), Northcentral University, Prescott Valey, Arizona.

Chase, N. M., \& Clegg, B. (2013). Effects Of Email Utilization On Higher Education Professionals. In User Perception and Influencing Factors of Technology in Everyday Life (pp. 233-247). IGI Global.

Churchill, D. (2007). Towards A Useful Classification Of Learning Objects. Educational Technology Research and Development, 55(5), 479-497.

Chuttur, M. Y. (2009). Overview Of The Technology Acceptance Model: Origins, Developments And Future Directions. Working Papers on Information Systems, 9(37), 937.

Davis, F. D. (1985). A technology acceptance model for empirically testing new end-user information systems: Theory and Results. (Ph.D.), Massachussetts Institute of Technology, Massachusetts.

Davis, F. D., Bagozzi, R. P., \& Warshaw, P. R. (1989). User acceptance of computer technology: a comparison of two theoretical models. Management science, 35(8), 9821003.

Dulcic, Z., Pavlic, D., \& Silic, I. (2012). Evaluating the Intended Use of Decision Support System (DSS) by Applying Technology Acceptance Model (TAM) in Business Organizations in Croatia. Procedia - Social and Behavioral Sciences, 58, 1565-1575. doi:10.1016/j.sbspro.2012.09.1143

Edmunds, R., Thorpe, M., \& Conole, G. (2012). Student attitudes towards and use of ICT in course study, work and social activity: A technology acceptance model approach. British Journal of Educational Technology, 43(1), 71-84. doi:10.1111/j.14678535.2010.01142.

Ertmer, P. A. (1999). Addressing first-and second-order barriers to change: Strategies for technology integration. Educational technology research and development, 47(4), 47-61.

Fathema, N., Shannon, D., \& Ross, M. (2015). Expanding the Technology Acceptance Model (TAM) to examine faculty use of Learning Management Systems (LMSs) in higher education institutions. MERLOT Journal of Online Learning and Teaching, 11(2), 210232.

Fishbein, M., \& Ajzen, I. (1975). Belief, Attitude, Intention and Behavior. An Introduction to Theory and Research. Canada: Addison-Wesley Publishing Company.

Fry, N., \& Love, N. (2011). Business Lecturers' Perceptions and Interactions with The Virtual Learning Environment. International Journal of Management Education, 9(4), 51-56.

$\mathrm{Fu}$, J. S. (2013). ICT in Education: A Critical Literature Review and Its Implications. International Journal of Education and Development using Information and Communication Technology, 9(1), 112.

Gan, C. L., \& Balakrishnan, V. (2014). Determinants of mobile wireless technology for promoting interactivity in lecture sessions: An empirical analysis. Journal of Computing in Higher Education, 26(2), 159-181.

Ha, S., \& Stoel, L. (2009). Consumer E-Shopping Acceptance: Antecedents In A Technology Acceptance Model. Journal of Business Research, 62(5), 565-571.

Hernández, B., Jiménez, J., \& Martín, M. (2008). Extending the Technology Acceptance Model to Include the IT Decision-Maker: A Study of Business Management Software. Technovation, 28(3), 112-121. doi:10.1016/j.technovation.2007.11.002 
Jurnal Manajemen Bisnis, Vol 9. No 2, September 2018, E-ISSN:2622-6308 P-ISSN:2086-8200

Website: http://journal.umy.ac.id/index.php/mb

DOI:10.18196/mb.9264

Hudson, K. (2010). Working Together: The Role of Collaborations in Promoting the Use of Academic Technologies in Higher Education. (3427536 Ed.D.), University of Massachusetts Amherst, Ann Arbor. Retrieved from http:// search.proquest.com/docview/816503205?accountid=10424 ProQuest Dissertations \& Theses Global database.

Iqbal, S., \& Bhatti, Z. A. (2015). An Investigation of University Student Readiness towards M-learning using Technology Acceptance Model. International Review of Research in Open and Distance Learning, 16(4).

Jan, A. U., \& Contreras, V. (2011). Technology Acceptance Model for the Use of Information Technology in Universities. Computers in Human Behavior, 27(2), 845-851. doi:10.1016/j.chb.2010.11.009

Kabir, Y. (2012). Impact of information and communication technology on teaching of business education courses in colleges of education in Nigeria. (Master of Education), Ahmadu Bello University, Nigeria.

Khan, M., Hossain, S., Hasan, M., \& Clement, C. K. (2012). Barriers to the Introduction of ICT into Education in Developing Countries: The Example of Bangladesh. International Journal of instruction, 5(2).

King, W. R., \& He, J. (2006). A Meta-Analysis of the Technology Acceptance Model. Information \& management, 43(6), 740-755.

Kirkup, G., \& Kirkwood, A. (2005). Information And Communications Technologies (ICT) in Higher Education Teaching-A Tale Of Gradualism Rather Than Revolution. Learning, Media and Technology, 30(2), 185-199.

Lane, L. M. (2008). Toolbox or trap? Course Management Systems and Pedagogy. Educause Quarterly, 31(2), 4.

Lane, M., \& Stagg, A. (2014). University Staff Adoption of IPad: An Empirical Study Using an Extended Technology Acceptance Model. Australasian Journal of Information Systems, 18(3), 53-74.

Leidner, D. E., \& Jarvenpaa, S. L. (1995). The Use of Information Technology to Enhance Management School Education: A Theoretical View. MIS Quarterly, 265-291.

Marangunić, N., \& Granić, A. (2015). Technology Acceptance Model: A Literature Review from 1986 to 2013. Universal Access in the Information Society, 14(1), 81-95. doi:10.1007/s10209-014-0348-1

Nawaz, A., \& Khan, M. Z. (2012). Issues of Technical Support for e-Learning Systems in Higher Education Institutions. International Journal of Modern Education and Computer Science (IJMECS), 4(2), 38.

Noguera, J. H., \& Watson, E. F. (2004). Effectiveness of Using an Enterprise System to Teach Process-Centered Concepts in Business Education. Journal of Enterprise Information Management, 17(1), 56-74. doi:10.1108/09576050410510953

Noor-Ul-Amin, S. (2013). An Effective Use of ICT for Education and Learning by Drawing On Worldwide Knowledge, Research, and Experience: ICT as A Change Agent for Education. Scholarly Journal of Education, 2(4), 38-45.

Pasaoglu, D. (2011). Analysis of ERP Usage with Technology Acceptance Model. Global Business and Management Research: An International Journal, 3(2), 157.

Penmenristekdikti (Peraturan Menteri Riset, Teknologi, Dan Pendidikan Tinggi Republik Indonesia) (2015).

Diunduh dari https://img.akademik.ugm.ac.id/unduh/2015/PERMENRISTEKDIKTI_ Nomor_44_Tahun_2015_SNPT.pdf 
Jurnal Manajemen Bisnis, Vol 9. No 2, September 2018, E-ISSN:2622-6308 P-ISSN:2086-8200

Website: http://journal.umy.ac.id/index.php/mb

DOI:10.18196/mb.9264

Persaud, B. (2006). School Administrators' Perspective On Their Leadership Role In Technology Integration. (Doctor of Philosophy Education), Walden University.

Plouffe, C. R., Hulland, J. S., \& Vandenbosch, M. (2001). Research Report: Richness versus Parsimony in Modeling Technology Adoption Decisions - Understanding Merchant Adoption of A Smart Card-Based Payment System. Information Systems Research, 12(2), 208-222.

Raman, A. (2011). The Usage of Technology among Education Students in University Utara Malaysia: An Application of Extended Technology Acceptance Model. International Journal of Education and Development using Information and Communication Technology, $7(3), 4$.

Redmann, D. H., \& Kotrlik, J. W. (2004). Technology Integration into the Teaching-Learning Process by Business Education Teachers. Delta Pi Epsilon Journal, 46(2), 76-91.

Reigeluth, C. M., Watson, W. R., Watson, S. S. L., Dutta, P., Chen, Z., \& Powell, N. D. (2008). Roles For Technology In The Information-Age Paradigm Of Education: Learning Management Systems. Educational Technology, 32-39.

Renes, S. L., \& Strange, A. T. (2011). Using Technology to Enhance Higher Education. Innovative Higher Education, 36(3), 203-213. doi:10.1007/s10755-010-9167-3

Rienties, B., \& Townsend, D. (2012). Integrating ICT in Business Education: Using TPACK to Reflect on Two Course Redesigns. In Learning at the Crossroads of Theory and Practice (pp. 141-156). Springer, Dordrecht.

Rogers, E. M. (1983). Diffusion of innovations. New York: Free Press.

Sarkar, S. (2012). The Role of Information and Communication Technology (ICT) in Higher Education for the 21st century. Science, 1(1).

Sekaran, U., \& Bougie, R. (2016). Research Methods For Business: A Skill Building Approach. John Wiley \& Sons.

Shahrabi, M. A., Ahaninjan, A., Nourbakhsh, H., Ashlubolagh, M. A., Abdolmaleki, J., \& Mohamadi, M. (2013). Assessing Psychometric Reliability and Validity of Technology Acceptance Model (TAM) Among Faculty Members at Shahid Beheshti University. Management Science Letters, 3(8), 2295-2300. doi:10.5267/j.msl.2013.07.014

Snyder, K. D. (2003). Ropes, Poles, and Space: Active Learning in Business Education. Active Learning in Higher Education, 4(2), 159-167. Doi: 10.1177/1469787403004002004

Sugiyono, P. (2015). Metode penelitian kombinasi (mixed methods). Bandung: Alfabeta.

Šumak, B., HeričKo, M., \& Pušnik, M. (2011). A Meta-Analysis of E-Learning Technology Acceptance: The Role of User Types and E-Learning Technology Types. Computers in Human Behavior, 27(6), 2067-2077.

Thomas, C. D. (2011). Factors Affecting Faculty Use of Technology-Enhanced Instruction at Research Universities. (Doctor of Philosophy), the University of Texas Austin.

Thomas, P. H., Jr. (2012). Predicting Information Technology Adoption in Small Businesses: An Extension of the Technology Acceptance Model. Academy of Information and Management Sciences Journal, 15(1), 37.

Turner, M., Kitchenham, B., Brereton, P., Charters, S., \& Budgen, D. (2010). Does The Technology Acceptance Model Predict Actual Use? A Systematic Literature Review. Information and Software Technology, 52(5), 463-479. doi:10.1016/j.infsof.2009.11.005

Venkatesh, V., \& Bala, H. (2008). Technology Acceptance Model 3 and a Research Agenda on Interventions. Decision sciences, 39(2), 273-315.

Venkatesh, V., \& Davis, F. D. (2000). A Theoretical Extension of the Technology Acceptance Model: Four Longitudinal Field Studies. Management science, 46(2), 186-204. 
Watty, K., McKay, J., \& Ngo, L. (2015). Innovators or Inhibitors? Accounting Faculty Resistance to New Educational Technologies in Higher Education. Journal of Accounting Education. doi:10.1016/j.jaccedu.2016.03.003

Weisblat, G. Z., \& McClellan, J. (2017). The Disruptive Innovation of Self-Organized Learning Environments. Childhood Education, 93(4), 309-315.

Wright, R. P., Paroutis, S. E., \& Blettner, D. P. (2013). How Useful Are the Strategic Tools We Teach in Business Schools? Journal of Management Studies, 50(1), 92-125. doi:10.1111/j.1467-6486.2012.01082.

Wu, K., Zhao, Y., Zhu, Q., Tan, X., \& Zheng, H. (2011). A Meta-Analysis of The Impact of Trust on Technology Acceptance Model: Investigation of moderating influence of subject and context type. International Journal of Information Management, 31(6), 572581.

Yin, R. K. (2009). Case study research: design and methods (Vol. 5.). Thousand Oaks, Calif: Sage Publications.

Yousafzai, S. Y., Foxall, G. R., \& Pallister, J. G. (2007). Technology Acceptance: A MetaAnalysis of the TAM: Part 2. Journal of Modelling in Management, 2(3), 281-304. doi: $10.1108 / 17465660710834462$ 